\title{
MICRO, SMALL AND MEDIUM ENTERPRISES SERVICE AT INVESTMENT AND ONE-STOPINTEGRATED SERVICES OFFICE MANADO CITY
}

\author{
By \\ Chyntia Maria Siwi ${ }^{1}$, Jeane Mantiri' ${ }^{2}$, Thiar Sitorus ${ }^{3}$ \\ ${ }^{1}$ Faculty of Law, Social and Political Sciences, Terbuka University, Indonesia \\ ${ }^{2,3}$ Faculty of Social Science, Manado State University, Indonesia \\ Email: ${ }^{1}$ mariasiwi@ecampus.ut.ac.id, ${ }^{2}$ jeanelitha@unima.ac.id, ${ }^{3}$ thiaryulisa@gmail.com
}

\begin{abstract}
Article Info
Article History:

Received:13-10-21

Revised : 16-11-21

Accepted: 24-11-2021

Keywords:

Licensing Service, Micro,

Small and Medium Enterprises, Manado City

ABSTRACT

This study aimstodescribe, micro, smalland medium businesslicensingservices in theinvestmentofficeandone-stop integratedservice in Manado City. This study uses a qualitativeapproach, with data collectiontechniquesnamelyobservation, documentation, and semi-structuredinterviews. The results of the research show that 1) Regarding the process of coordinating the management of business licenses, the community does not yet know about the mechanism for managing business permits, so seeing the targets to be achieved can be said to be not optimal because, in the process of obtaining permits, people still find it difficult. 2) Regarding the management of the completion of service activities to the community related to how long the process of completing a business license, it can be seen that it is still not per the Operational Standards applied at the One-Stop Integrated Service and InvestmentService because the process of making a business license takes a long time.
\end{abstract}

Thisisanopen-accessarticleundertheCC BY-SAlicense.

CorrespondingAuthor:

Maria Chyntia Siwi,

Faculty of Law, Social and Political Sciences,Terbuka University

Email: mariasiwi@ecampus.ut.ac.id

\section{INTRODUCTION}

Economic business in Indonesia is a very important thing for the Indonesian people, where the Indonesian people are free to choose how to determine to get a prosperous economy. In the past few years, Indonesia was hit by a monetary and economic crisis that had quite severe consequences for the Indonesian economy. This has caused many companies that have grown large in Indonesia to go bankrupt and some fewer investors want to invest in Indonesia. With this crisis, the government must review the policies that have been focused on large companies to divert attention to the small and medium industry sector. Micro, Small, and Medium Enterprises, or what is often abbreviated as MSMEs is an important part of the economy of a country or region, as well as Indonesia[1]. MSMEs have a very important role in the community's economy.

These MSMEs can greatly assist the State and the government in terms of creating new jobs and through MSMEs, many new work units have also been created that can use new workers to support household income. In addition, MSMEs also have very high flexibility when compared to businesses with a larger capacity. These MSMEs need proper attention and are supported through accurate information, so that directed business links can occur between small and medium business actors by elements of business competitiveness, namely market networks. MSMEs play a very large role in the economy so that MSMEs are mentioned on various occasions as truly the backbone of the economy, especially in Indonesia. MSMEs have contributed to economic development and are the drivers of increasing non-oil and gas exports, the contribution given by MSMEs can be even greater through economic development if they can continue to be developed.

In addition, Micro, Small, and Medium Enterprises are one of the main pillars of the national economy that must get the main opportunity, support, protection, and development as widely as possible as a form of firm alignment with people's economic business groups, without neglecting the role of Large Enterprises and Business Entities. State-Owned[2]. Micro, Small, and Medium Enterprises are now able to play a role in the national 
economy, but they still face various obstacles and constraints, both internal and external, concerning production, processing, marketing, human resources, design, technology, capital, and business climate[3]. In increasing the opportunities, capabilities, and protection of Micro, Small, and Medium Enterprises, several policies regarding business reserves and funding have been set. Its development is still not optimal, due to this the policy has not been able to provide protection, business certainty, and adequate facilities in empowering Micro, Small, and Medium Enterprises. Therefore, it is necessary to empower MSMEs so that the goals of the government can be achieved by Article 5 of Law Number 20 of 2008 which reads: The purpose of empowering Small, Micro and Medium Enterprises of Law Number 20 of 2008 paragraph (1) Realizing services, licensing, management a balanced, developing, and just national economic structure; (2) Growing and developing the ability of Micro, Small, and Medium Enterprises to become strong and independent businesses; and Increasing the role of Micro, Small, and Medium Enterprises in regional development, job creation, income distribution, economic growth, and alleviating people from poverty[4].

In Government Regulation Number 17 of 2013 concerning the implementation of Law Number 20 of 2008 concerning Micro, Small and Medium Enterprises, Article 2 paragraph (1) the Government and Regional Governments per their authority to organize Empowerment of Micro, Small and Medium Enterprises, paragraph (2) The empowerment of micro, small and medium enterprises as regulated in paragraph (1) is carried out by a. business development b. partnership c. licensing and d. coordination and control. One-Stop Integrated Service Service is an office that is a place for making business permits by applicable regulations, as regulated in Government Regulation Number 17 of 2013 Article 6 paragraph (1) Government and Regional Governments Prioritize Development of Micro, Small and Medium Enterprises through a. Providing opportunities to participate in the procurement of goods and services of the Government and Regional Government b. Business declaration for micro, small and medium enterprises through restrictions for large enterprises c. ease of licensing[5].

In the Minister of Home Affairs Regulation Number 138 of 2017 Article 1 one-stop integrated service, hereinafter abbreviated as One-Stop Integrated Service, is an integrated service in a single process starting from the application stage to the stage of completing the service product through one door, the organizer of the One-Stop Integrated Service regional government officials by the authority based on statutory regulations, one-stop integrated service providers are licensing and non-licensing operations whose implementation process starts from the application stage to the issuance stage of documents carried out in an integrated manner in one door and one place, in article 2 the purpose The implementation of regional One-Stop Integrated Services is to improve the quality of OneStop Integrated Services, to realize legal protection and certainty for the community, to provide wider access to the community to obtain excellent service and to improve the quality of life. improve the ease of doing business and regional competitiveness[6]. The Manado City Investment and One-Stop Integrated Service Office is led by the Head of the Office who is located under and responsible to the Mayor through the Regional Secretary. The Manado City One-Stop Integrated Service and Investment Service serves 4 types of permits, namely the type of economic sector permit, the type of development permits, types of permits in the environmental and transportation sectors, types of permits in the social sector. The implementation of One-Stop Integrated Services such as the Investment Office and One-Stop Integrated Services has the aim of improving the quality of good and clean governance, the competitiveness of the city's economy, as well as a fast and convenient public service and licensing system.

However, according to the findings made by the researchers, it was found that the One-Stop Integrated Service and Investment Service, in this case, the Economic Licensing Sector, in administering the permit is per the applicable mechanism, but there are still obstacles that make the community feel difficult, including The processing of business permits takes a long time, up to three weeks or almost 1 month, it was also found that most people do not know about the procedures for obtaining business permits, so people have to go back and forth to complete the business permit application documents. Operational standards applied by the Office of Investment and One-Stop Integration One-Stop services so that the target to be achieved in making business licenses will continue to decline, according to the results of data from the Manado Integrated Licensing Service Information System, Investment Office,andOne-Stopp Integrated Services, for applicants, However, in the management of permits up to the issuance of decrees, business licenses have decreased, which in 2020 amounted to 3085 requests for control and business decrees issued 2970, in 2021 for new control applications there were 1511 and for business issuance decrees amounted to 1278. Regulation of the Minister of the Interior State Government Number 138 of 2017 concerning the Implementation of Regional OneOne-Stoprvices, article 12 In the implementation of Licensing and Non-licensing services, local governments are obliged to prepare, determine, and implement (a) service standards; and (b) standard operating procedures[6].

Componentsof Standard OperatingProcedures as referredto in Article 12 letter b include a). severalstandardoperatingprocedures; b. dateofmanufacture; c). revisiondate; d). validationdate; e). endorsedby; f) .nameofstandardoperatingprocedure; g. legal basis; h. implementingqualifications; i. linkages; $\mathrm{j}$. 
International Journal of Social Science (IJSS)

Vol.1 Issue.4 December 2021, pp: 399-406

ISSN: 2798-3463 (Printed) | 2798-4079 (Online)

DOI: https://doi.org/10.53625/ijss.v1i4.717

equipmentandsupplies; $\mathrm{k}$. warning; 1 . recordingand data collection; $\mathrm{m}$. proceduredescription; $\mathrm{n}$. executor. $\mathrm{o}$. completeness; p. time; and q. Output[7]. However, if you look at the SOPs implemented by the Manado City Investment and One-Stop Integrated Services Agency, it is still not as expected. The excellent service provided by the government as the relevant agency and the ease of obtaining permitsis very important in the national development process to be able to expand employment opportunities. There needs to be support and protection from the government and cooperation from every stakeholder.

\section{RESEARCH METHOD}

This research will be carried out with a qualitative approach, because qualitative research emphasizes the process of finding meaning, revealing meaning, behind the phenomena that arise in research, with the aim that the problems to be studied are more comprehensive, in-depth, natural, and as they are and without interference. from the researcher to the facts that emerge. In general, the reason for using qualitative methods is because the problems are not clear, holistic, complex, dynamic, and full of meaning so that data on social situations can't be captured by quantitative research methods with instruments such as tests, questionnaires. In addition, the author intends to understand social situations in-depth, find patterns, hypotheses, and theories[8]. Thus, this study is intended to provide a description, an overview of the Utilization of MSME Business License Services at the Investment and One-Stop Service Office in Manado City.The focus of the research is Micro, Small and Medium Business License Services at the Office of Capital Services and One-Stop Integrated Services, Manado City, and which is the subfocus according to the research data in the field, the sub-focus discussed from public service management is focused on the Process of Coordination and Completion of Service Activities.

Based on the problems and objectives of this study, the data sources are as follows[9]:

1) Primary Data, Informants are the first informants determined purposively (purposive sampling), this is intended to select informants who are truly relevant and competent to the research problem so that the data obtained are used to build conclusions. Meanwhile, the informant was then asked the initial informant to appoint another person who could provide information, and then the informant referred to another person who could refer it so that the next informant referred to other people who were considered able to provide more information, and so on. The first informants selected by the researcher purposively were the informants in this study consisting of the Banjer village community, the TelingMahkeret village community, the Taas village community,and employees of the One-StopInvestment and Integrated Service Office, namely the Head of the Economic Licensing Control Division, the Head of the Economic Licensing Publishing Section, Freelance Daily Employee in the Issuance of Economic Licensing.

2) Secondary data is data obtained from regulatory regulations that have been set by the government, reading sources, and various other sources consisting of social media state civil apparatus, minutes of association meetings, to official documents from various government agencies. Secondary data can be in the form of magazines, bulletins, publications from various organizations, attachments from official bodies such as ministries, study results, theses, survey results, study histories, and others. Researchers get secondary data to strengthen the findings and complement the information that has been collected in direct interviews.

3) Places and Events. Places and events referred to here are places where researchers obtain data, namely at the Manado City One-Stop Integrated Service and Investment Service by observing the phenomena that occur in the field.

4) Documents. In this study, researchers provide documents that are relevant to the problem and focus of research in the form of notes, photos/pictures.

\section{RESULTS AND ANALYSIS}

\subsection{Overview of Research Sites}

The Manado City Investment and One-Stop Integrated Service Office is an institution that plays a strategic role and function in the field of Manado City integrated licensing services, which was formed based on the Manado City Regional Regulation Number 02 of 2016 concerning the formation and composition of the Manado city regional apparatus as amended by Manado City Regional Regulation Number 2 of 2016 concerning the formation and arrangement of the Manado City area. The main task of the Manado City Investment and One-Stop Integrated Service Office is to assist the mayor in carrying out some government affairs in the field of investment and one-stop integrated services. The main tasks and functions of the Manado City Investment and One-Stop Integrated Service Office are[10]:

1. Assist the Mayor in carrying out government affairs in the field of investment and the implementation of one-stop integrated services. 
2. In carrying out the tasks as referred to in paragraph (1), the one-stop integrated investment and service office carries out the functions of::

a. Formulation of policies in the field of investment and one-stop integrated services;

b. Implementation of policies in the field of investment and one-stop integrated services;

c. Implementation of evaluation and reporting in the field of investment and one-stop integrated services;

d. Administration in the field of investment and one-stop integrated services;

e. Implementation of technical operational activities of promotion and investment cooperation,

f. Implementation of technical operational planning and investment development activities,

g. Implementation of technical operational activities for supervision and control of investment,

h. Implementation of technical activities for one-stop integrated service operations,

i. Implementation of operational technical activities of data, information, and service for complaints and regulations

j. Implementation of technical operational activities of licensing and non-licensing economic, social, development, and environmental;

k. Carrying out other tasks assigned by the mayor.

The one-stop investment and integrated service agency have the authority to issue and sign permits and/or non-licensing on behalf of the regional head based on the delegation of authority from the regional head. The onestop investment and integrated service agency have a strategic role in supporting the achievement of the 4th mission of Manado City, namely: "Building a city that has "competitiveness" by being oriented towards increasing investment attractiveness and the quality of public services based on information and communication technology." The aims and objectives of the mission are: Improving the quality of good and clean governance, the competitiveness of the city's economy, as well as a fast and convenient public service and licensing system.

With a target, a. increasing number of investors/investment value in Manado city, b. increasing public satisfaction with public services. The affirmation of the objectives of the vision and mission based on the strategic role of the Manado City Investment and One-Stop Integrated Service Office is to "increase regional investment by creating quality licensing services to increase the community satisfaction index for public services, especially onestop integrated services.

\subsection{Result}

Micro, Small, and Medium Enterprises are business activities that can expand employment opportunities and provide broad economic services to the community and can play a role in the process of equity and increase people's income, encourage economic growth, and play a role in realizing national stability. In addition, Micro, Small, and Medium Enterprises are one of the main pillars of the national economy that must obtain the main opportunity, support, protection, and development as widely as possible as a form of firm alignment with the people's economic business group. To achieve this, the government supports ease of doing business for micro, small and medium enterprises. The Ministry of Finance issued a procedure to simplify licensing through One Single Submission (OSS). Then provide relief from licensing fees for the formation of small businesses and exemption from licensing fees for micro-businesses as well as financial support for small and medium enterprises (UMK).

The investment agency itself has implemented a licensing process in the new institution known as One Single Submission (one-stop service). The licensing process implemented by the Manado city government through the Investment Service and One-Stop Integrated Service is expected to facilitate the process of carrying out licensing so that all MSMEs can carry out business activities per the procedures established by the Manado city government.However, in the development of controlling business licenses at the Investment and One-Stop Service Office, there has been a decline, both in the decline in requests for processing permits to controlling business license decrees, which in 2020 for controlling applications amounted to 3085 and for business decrees issued 2970, in 2020. 2021 for new control applications totaling 1511 and for business decrees numbering 1278. Presidential Regulation Number 98 of 2014 has set the legal basis for micro and small business permits (MSMEs) in addition that it is also regulated in PermendagriNomor 83 of 2014 concerning guidelines for granting micro-business permits. small.

This research is based on data from research results infield, the researchers focus more on the management of public services, for the description of the research, the researcher will discuss according to the indicators of Service Management according to Atik and Ratminto,4 main things appear in management, namely the planning process, Implemimplementationans, Coordination, and Completion of service activities. However, according to the data and research results in the field, the indicators discussed from public service management are focused on the Coordination and Completion Process of Service Activities.

\subsection{Discussion}

Public Services are all forms of services, both in the form of public goods and public services which in principle are the responsibility and are carried out by the Central Government, Regional Governments, State-Owned 
International Journal of Social Science (IJSS)

Vol.1 Issue.4 December 2021, pp: 399-406

ISSN: 2798-3463 (Printed) | 2798-4079 (Online)

DOI: https://doi.org/10.53625/ijss.v1i4.717

Enterprises, in the context of efforts to meet the needs of the community as well as in the context of implementing the provisions of the Law. Law No. 25 of 2009 concerning public services, defines that public services are activities or a series of activities in the context of fulfilling service needs in accelerant regulations for every citizen and resident of goods, services, and or administrative services provided by public service providers[11].

Micro, Small, and Medium Enterprises are one of the main pillars of the national economy that must obtain the main opportunity, support, protection, and development as widely as possible, as a form of firm alignment with people's economic business groups, without neglecting the role of Large Enterprises and State-Owned Enterprises. In Micro, Small, and Medium Enterprises now being able to show their role in the national economy, empowering Small, Micro and Medium Enterprises Law Number 20 of 2008 paragraph (1) Realizing services, licensing, managing the structure of the national economy that is balanced, developing, and just;(2 ) Growing and developing the ability of Micro, Small, and Medium Enterprises to become strong and independent businesses; and Increasing the role of Micro, Small, and Medium Enterprises in regional development, job creation, income distribution, economic growth, and alleviating people from poverty[4].

One-Stop Integrated Service Service is an agency that is a place for making business permits in acceptable regulations, as regulated in Government Regulation Number 17 of 2013 Article 6 paragraph (1) Government and Regional Governments Prioritize Development of Micro, Small and Medium Enterprises through a. Providing opportunities to participate in the procurement of goods and services of the Government and Regional Government b. Business declaration for micro, small and medium-sized businesses through restrictions for large businesses with ease of licensing[5].

The Manado City Investment and One-Stop Integrated Service Office is led by a Head of Service who is under and responsible to the Mayor through the Regional Secretary for the Manado City Investment and One-Stop Integrated Service. types of licensing in the environmental sector, types of licensing in the social sector One-stop regional integrated services have been described in the Minister of Home Affairs Regulation Number 138 of 2017 Article 1 one-stop integrated service, hereinafter abbreviated as One-Stop Integrated Service, is an integrated service in a single process starting from the application stage. until the stage of completion of service products through one door, regional One-Stop Service providers are local government officials in accordance with the authority based on laws and regulations, One Stop Integrated Service providers are local government officials licensing and nonlicensing whose implementation process starts from the application stage to the issuance stage of the document is carried out in an integrated manner in one door and one place, in article 2 the purpose of implementing regional OneStop Integrated Services is to improve the quality of One-Stop Integrated Services to realize legal protection and certainty for the community. , provide wider access to the community to obtain excellent service and improve the ease of doing business and regional competitiveness.

Service management plays a major role in carrying out services in accordance with the applicable Standard Operating Procedures, Regulation of the Minister of Home Affairs Number 138 of 2017 concerning the Implementation of Regional One Stop Services, Article 12 In the implementation of Licensing and Non-licensing services, local governments are obliged to prepare, determine, and implement ( a) service standards; and (b) standard operating procedures[6]. So far, service to the community is very important and should receive special attention from the Government, especially the Office of Investment and One-Stop Integrated Services which is an agency that is closely related to the business permit service process. the economy of a region, but the inhibiting factor for a business not developing is the absence of legality of business licenses, the role of the DPMPTS Office related to the management of business permits is very important, but the services provided must also be a top priority so that the community does not feel burdened in terms of business license management. The service is said to be of high quality or satisfactory if the service can meet the needs and expectations of the community [12].

1) Coordination Process

Coordination is the activity of connecting, unifying and harmonizing people and their work so that everything takes place in an orderly and rhythmic manner towards the achievement of goals without confusion or strife. The need for coordination depends on the nature and need for communication in the implementation of the Task and the degree of interdependence of the various units of implementation. According to Firdaus, management functions consist of planning, organizing, directing, coordinating and controlling. Planning is essentially a basic function of management or company leadership. The existence of planning provides a comprehensive view of the work that must be done and can be a demand for the achievement of organizational goals that have been set to be effective and efficient. Although future events cannot be determined with certainty (uncertainty), especially factors that are beyond the reach of the company (uncontrollable), through the preparation of good planning it is hoped that the results will approach

\footnotetext{
Journal homepage: https://bajangjournal.com/index.php/IJSS
} 
the goals set in the body of knowledge management, planning is a muscle and a vein, that is part of management that causes movement in the desired direction [13].

From the results of the research on the first indicator, what the researcher did is that the process of coordinating the management of business licenses carried out by the Manado City Investment and One-Stop Integrated Service Office was running well, based on the results of interviews conducted by researchers with several employees at the Investment and Integrated Services Agency. One Stop Manado City that the planning process has been going well, for example, related to the permit process, the Investment and One Stop Integrated Service Office in managing letter permits some stages must be followed in obtaining permits, starting from the application until the end of the license.

However, there were some weaknesses found related to the permit processing process, if you look at the Government's efforts, in this case, the One-Stop Integrated Service and Investment Service, which knows the mechanism for applying for a business license, but the obstacle is that the community does not know about the requirements in applying for a business license. do business licenses due to lack of information received due to the absence of socialization related to the mechanism for managing business licenses, lack of coordination and socialization which will have an impact on business license management services, it was also found that some people still find it difficult with the new system implemented by the Investment and Service Office. One Stop Services, the procedure for making business licenses must register through the link of the Office of Investment and One Stop Integrated Services, which should be the Government in issuing the permit management system to carry out socialization or further notification. so that problems like this do not occur, so that complaints that occur in the community result in a negative perspective on the government. In Manado Mayor Regulation Number 40 of 2020 Article 5 paragraph (1) Applicants have the right to obtain information and explanation regarding the administration of permits, because according to the findings that there are people who do not know about the socialization of the mechanism for managing permits, so that people do not know about the mechanism for administering permits. business permit. Weak response to the community so that people repeatedly come to the Office of Investment and One Stop Integrated Services to complete the file[14].

Minister of Home Affairs Regulation Number 138 of 2017 concerning the Implementation of Regional One Stop Services, Article 15 in the implementation of licensing services, the management of One Stop Services in letter (e) must provide counseling to the public. The Office of Investment and One Stop Integrated Services as the field that issues economic business licenses has already conducted socialization and also installed terms and conditions through flyers or bulletin boards, but admittedly it is still not optimal due to limited human resources and budget[6].

2) Completion of service activities

In terms of completing service activities in the management of business licenses, the Office of Investment and One Stop Integrated Services knows about the mechanism for managing business licenses, as evidenced so far by the issuance of all business permits, the Office of Investment and One Stop Integrated Services per its statement, Every community who manages permits business, must go through the applicable mechanism, so when the applicant enters the file at the service counter, later there will be a team that checks the file, usually, if it is incomplete, we give 7 days to complete the file, when it is complete there will be a technical team that will conduct a survey, after that no later than 3-4 working days, so that's the mechanism for controlling business licenses.

However, in accordance with the findings that the process of issuing a business license still takes a long time, it is not in accordance with the Operational Standards applied by the Office of Investment and One-Stop Integrated Services, according to the results of interviews with the public who said that the time for completing the processing of files for management and after the fix, they said later there will be a notification by telephone when it has become a business license, I waited for almost 2 weeks, but there was no notification by telephone, I had to go to the office, and thankfully there was a business license, I don't know when it will be issued, because it will be said later there is a notification, it could be that the business license has been issued a week ago because the office is far away so I came two weeks after that.

Excellent Service is a person's maximum ability in dealing with others in terms of service. Excellent service is the best service provided to customers, both internal and external customers based on service standards and procedures[15]. Success in developing and implementing excellent service cannot be separated from the ability to choose the approach concept. The concept of excellent service is based on A6, namely developing excellent service by aligning the concepts of Attitude, Attention, Action, Ability, Appearance, and Accountability[16]. 
International Journal of Social Science (IJSS)

Vol.1 Issue.4 December 2021, pp: 399-406

ISSN: 2798-3463 (Printed) | 2798-4079 (Online)

DOI: https://doi.org/10.53625/ijss.v1i4.717

\section{CONCLUSION}

Based on the results of the research data obtained, the researchers describe and analyze the above regarding the discussion in the previous chapter, it can be concluded from the research on Micro, Small and Medium Enterprises Licensing Services at the Manado City Investment and One Stop Integrated Service Office, as follows:

a. The community in the process of coordinating the management of business licenses does not yet know about the mechanism for managing business permits, so seeing the targets to be achieved can be said to be not optimal because, in the process of obtaining permits, the community still finds it difficult. The lack of socialization related to the mechanism for obtaining permits in the sector of economic licensing has an impact on people who are not aware of the mechanism. The advice given by the researcher is that it is better for the One-Stop Integrated Investment and Service Office, in this case, the economic licensing sector, to further improve coordination and conduct further socialization or notification related to the permit processing mechanism.

b. In the management of the completion of service activities to the community related to how long the process of completing a business license in the field of economic licensing, it can be seen that it is still not per the Operational Standards applied at the One-Stop Integrated Service and Investment Service because the process of making a business license is time-consuming. long, because in the operational standard of business license management, punctuality must be prioritized. The advice given by the researcher is that it is better for the OneStop Integrated Service and Investment Service, in this case the economic licensing sector in the issuance of business licenses, must be accelerated in accordance with applicable operational standards.

\section{REFERENCES}

[1] Y. M. Idah and M. Pinilih, "MSME Digitization Development Strategy," Pros. Semin. Nas. and Call Pap. "Sustainable Development of Rural Resources and Local Wisdom IX," vol. 9, no. 1, 2020.

[2] W. Rumbianingrum and C. Wijangka, "The Influence of Financial Literacy on MSME Financial Management," J. Manaj. and Business, vol. 2, no. 3, 2018.

[3] J. Mantiri, C. Siwi, and M. Korompis, "The Implementation of Micro Business Development in the Department of Cooperative and SMEs of Minahasa Regency," 2019.

[4] "Law Number 20 of 2008 concerning the Purpose of Empowering Small, Micro and Medium Enterprises."

[5] "Government Regulation Number 17 of 2013 concerning Community Organizations."

[6] "DOMESTIC GOVERNMENT REGULATION No. 138 of 2017 concerning the Implementation of Regional One Stop Services."

[7] A. R. Dilapanga, "Organizational Work Climate (Study at the Minahasa District Social Service)," J. Kaji. policy. and Science Adm. Country (JOURNAL Adm., 2020.

[8] Sugiyono, “Understanding Qualitative Research,” Bandung Alf., 2016.

[9] D. M. A. Lexy J. Moleong, "Qualitative Research Methodology (Revised Edition)," PT. Rosda Karya Youth, 2019.

[10] "Manado City Regional Regulation Number 02 of 2016 concerning Formation and Structure of Manado City Regional Apparatus."

[11] P. Public and P. R. Indonesia, "Law Number 25 of 2009 concerning "Public Services", Law Number 25 of 2009 concerning "Public Services", 2009.

[12] N. E. S. Tude, N. R. Pioh, and W. Waworundeng, "QUALITY OF PUBLIC SERVICES AT THE POPULATION AND CIVIL REGISTRATION SERVICES OF NORTH HALMAHERA REGENCY,” J. Jur. Government Science, Fak. Social Science. and Polit. Univ. Sam Ratulangi., vol. Volume 4 N, no. 23375736.

[13] M. Firdaus, Agribusiness Management. Jakarta: Earth Literacy, 2008.

[14] "Manado Mayor Regulation Number 40 of 2020.".

[15] N. W. Suwithi, Excellent Service (Customer Care). Jakarta: Papers, 1999.

[16] Barata, Basics of Excellent Service. Jakarta: Elex Media. Kom, 2003. 
THIS PAGE HAS INTENTIONALLY BEEN LEFT BLANK 